therefore worth testing. "The next-generation vaccines have not yet protected chimps," he adds. But one official at Genentech's parent company Hoffmann La-Roche says he is sure that "Genentech is well informed that gp120 is not very interesting for the future". Similarly, apart from the Thailand trials, Genentech's management is believed by many researchers to have pulled the plug on both the gp120 programme and AIDS vaccine research in general.

But most scientists seem to agree that it is time to explore a wider choice of research avenues. They argue, for example, that not enough attention has been given to so-called therapeutic vaccines which might attenuate infection to a level that could prevent the onset of AIDS, or transmission of the virus. Others argue that work on attenuated viruses merits much greater attention, despite the concerns about their safety.

In contrast, there has been growing criticism of the way that much AIDS vaccine research is directed at the B subtypes of HIV that are common in infections in the developed world. The OAR review is expected to recommend refocusing AIDS vaccine research on the HIV subtypes common in the developing world, where "a fire is raging", says one AIDS researcher.

The preliminary conclusions of the OAR reviews are echoed by an official at the European Commission, who claims that HIV vaccine research lacks both coordination and funding. The research directorate has recently created a task force on vaccines - headed by Bruno Hansen, formerly of Novo Nordisk - with other commission directorates. This will coordinate existing vaccine research within the European Union's Framework research programmes, and is seeking ECU100 million (US\$ 133.44 million) over the three years 1996-1998 for a scries of new programmes.

Another proposal comes from Seth Berkley from the Rockefeller Foundation in New York, who is trying to raise $\$ 600$ million over seven years to set up an International AIDS Vaccine Initiative. This would fund existing laboratories rather than create new structures, says Berkley.

But others remain sceptical about whether the scientific community can replace industry's role in vaccine development. Levy, for example, argues that in the absence of adequate animal models, Phase I trials - which are needed not to test vaccines, he emphasizes, but to obtain information - require industrial support.

France is home to the company Pasteur Mérieux Sérums et Vaccins - now a subsidiary of Rhône-Poulenc Rorer - which is one of the few large companies taking a broad interest in HIV vaccine research. The company is already developing one of the first so-called second-generation 'prime boost' vaccines, made of an avipox virus genetically engineered to produce subunit proteins, and designed to give both a humoral and cellular response. Declan Butler

\title{
Black scientist faces inquiry at South African university
}

Cape Town. A black South African scientist with an international reputation in immunology, head-hunted from Britain to a senior post at the University of the Witwatersrand (Wits), has become the centre of a fierce controversy about his fitness for office, amid speculation over his possible candidacy as the university's next vice-chancellor.

The university has set up a tribunal to look into allegations by 13 senior academics against William Makgoba, one of its deputy vice-chancellors. In a letter to the current vice-chancellor, Robert Charlton, the academics challenged statements made by Makgoba in various versions of his curriculum vitae, and allege that he has failed adequately to carry out the responsibilities of his current job.

The academics also claim that a series of public Makgoba: tribunal will statements made

by Makgoba about the university over the past year have undermined - and are thus incompatible with - the proper performance of these responsibilities.

Makgoba in turn has dismissed the allegations against him as an "orchestrated campaign of vilification and disinformation". He has declined an invitation to discuss the matter with Charlton, arguing that the outcome of such a meeting would be a foregone conclusion, and asking that the matter be handled on a formal basis.

Makgoba graduated from the University of Natal Medical School in 1976, and left South Africa shortly afterwards to pursue his studies overseas. He appeared to have impeccable credentials for his new post at Wits, to which he was appointed last year; at the time of his appointment, for example, he was a senior lecturer in immunology at the Royal London Postgraduate Medical School in the United Kingdom.

But last month, scarcely a year after he assumed office, a group of nine deans and four senior professors at Wits wrote a letter of complaint to Charlton. The allegations against Makgoba include falsely claiming membership of both the American Association of Immunology and the British Transplantation Society, and receiving a grant of $£ 80,000$ (US $\$ 128,000$ ) from the Nuffield Trust while at Oxford's John Radcliffe School of Medicine between 1979 and 1983.

Makgoba also wrongly claimed that a paper he co-authored in the journal Immunology Today in 1988 was the most- cited article in the life sciences in the following year. In the light of these charges, Charlton sent a letter inviting Makgoba and his legal representative to a meeting on 2 November, saying that this meeting was intended to satisfy him that "the allegations lacked weight and substance, and that there would be no need for further proceedings".

But Makgoba, who could not be contacted for comment, has said that he prefers to clear his name in front of a full committee of inquiry. "The thirtecn excellent academics got it so wrong it is incredible," he told the Johannesburg Sunday Times. "In conducting research by using Procrustean methods they will follow the fate of Procrustes," he said, adding that the Greek mythological figure - who used force to impose conformity - was himself eventually killed.

Some of Makgoba's critics have themselves come under fire for their tactics. Charles van Onselen, for example, a social historian, has been criticized for the methods he used to investigate Makgoba's claim that he was the first African graduate to obtain a distinction and a certificate of merit in medicine at the University of Natal. Rather than requesting the information directly, Onselen learned that no such award had been made by writing to the university registrar on the pretext of obtaining assistance with what he called "a rather esoteric inquiry for a piece of social history".

Last week, representatives of the Wits Black Staff Forum and the South African National Students' Congress accused a "white clique" of waging a vendetta against Makgoba and called for Charlton's resignation on the grounds that his handling of the matter and statements have polarized the university on racial lines. Makaziwe Mandela, an executive member of the forum, and daughter of President Nelson Mandela, claimed the university was trying to get rid of Makgoba because he had demonstrated his independence and intelligence.

But Charlton, who retires in 1997 , has been trying to play down the racial dimension. He has responded to critics such as Mandela by claiming that, while everything in South Africa is represented in racial terms, the complaints against Makgoba can be investigated objectively. "If he had been white, the complaints would have been the same," he added.

A three-person tribunal has been set up by the university to look into the affair. Lord Flowers, the former vice-chancellor of the University of London, and Walter Kamba, dean of law at the University of Namibia, have already agreed to be members. The third person has yet to be appointed.

Michael Cherry 